\title{
Peripheral developing odontoma in newborn. Report of two cases and literature review
}

\author{
Alan-Roger S. Silva ${ }^{1}$, Roman Carlos-Bregni ${ }^{2}$, Pablo-Agustin Vargas ${ }^{3}$, Oslei-Paes de Almeida ${ }^{4}$, Marcio-Aju- \\ darte Lopes 5
}

${ }^{1}$ DDS, MS, PhD student. Department of Oral Diagnosis (Semiology), Piracicaba Dental School, State University of Campinas (UNICAMP), Piracicaba, São Paulo, Brazil

${ }^{2}$ DDS, Head. Centro Clínico de Cabeza y Cuello, Guatemala City, Guatemala

${ }^{3}$ DDS, PhD, Associate Professor. Department of Oral Diagnosis (Oral Pathology), Piracicaba Dental School, State University of Campinas (UNICAMP), Piracicaba, São Paulo, Brazil

${ }^{4}$ DDS, PhD, Titular Professor. Department of Oral Diagnosis (Oral Pathology), Piracicaba Dental School, State University of Campinas (UNICAMP), Piracicaba, São Paulo, Brazil

${ }^{5}$ DDS, PhD, Titular Professor. Department of Oral Diagnosis (Semiology), Piracicaba Dental School, State University of Campinas (UNICAMP), Piracicaba, São Paulo, Brazil

Correspondence:

Faculdade de Odontologia de Piracicaba - UNICAMP.

Departamento de Diagnóstico Oral (Área de Semiologia).

Avenida Limeira, 901, Caixa Postal 52.

Piracicaba - SP, Brasil. CEP: 13414-903.

malopes@fop.unicamp.br

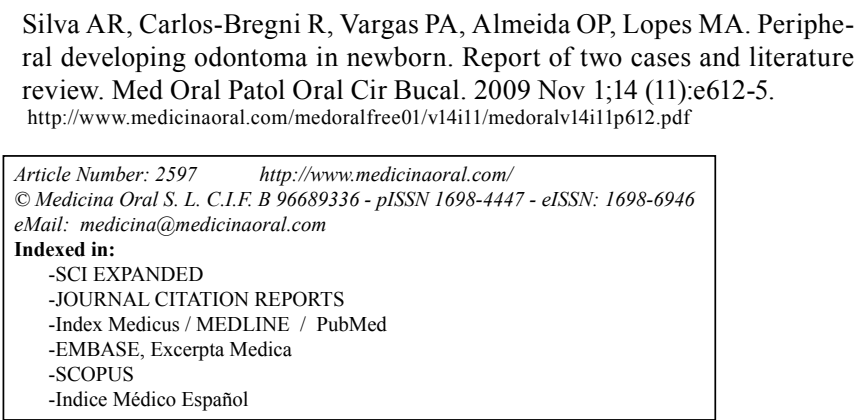

\begin{abstract}
Extra-osseous odontogenic tumors are rarely observed. However, it is widely accepted that the remains of odontogenic epithelium entrapped in the oral soft tissues may be a possible source for peripheral odontogenic tumors differentiation. Peripheral developing odontoma is considered exceptionally rare, since few similar cases are described in the English-related literature under diverse nomenclature, such as irregular eruption, ectopic tooth, ectopic soft-tissue mesiodens, ectopic odontoma and extra-osseous tooth germ. Previously reported cases invariably affected children and surgical exploration revealed tooth germs exclusively embedded in the soft tissue without bone involvement. Microscopically, all these cases exhibited developing tooth germs composed of ameloblasts, enamel matrix, odontoblastic layer, dentin and dental papilla and the morphological findings seem to depend on the developmental stage of each tooth germ at discovery. Thus, we believe that it is relevant to report two additional cases that were recently diagnosed in Brazil and Guatemala, focusing on their nomenclature, correct diagnosis and further treatment.
\end{abstract}

Key words: Odontogenic tumors, odontoma, child. 


\section{Introduction}

Odontogenic lesions in humans can show a wide variety of conditions such as cysts, hamartomas and tumors. Odontogenic tumors are uncommon, particularly in newborns where they are rarely observed $(1,2)$. The purpose of this article is to describe the clinical and histological features of two cases of peripheral developing odontoma, characterized by a nodular development of dental tissue on the palate of two newborn patients. Similar cases seem to be rare since few reports were published in the English-language literature under diverse nomenclature including irregular eruption, ectopic tooth, ectopic soft-tissue mesiodens and ectopic odontoma (3-7).

\section{Case Reports}

- Case 1: An 8-month-old boy was referred for examination of an asymptomatic, slowly-growing congenital nodule overlying the alveolar mucosa of the palate. During the first clinical examination, the lesion measured 1.0 $\mathrm{x} 1.0 \mathrm{~cm}$ in its maximum dimension (Figure 1A). With the clinical impression of congenital epulis of the newborn an excisional biopsy was performed under general endotracheal anesthesia. During the surgical procedure no sign of bone erosion beneath the lesion was detected (Figure 1B). Post surgical healing was uneventful. Histopathological examination displayed a surface stratified squamous epithelium covering a developing tooth germ composed of dental papilla, stellate reticulum, stratum intermedium, ameloblasts, enamel matrix and dentin (Figures 2A-2C). The tooth germ was totally surrounded by fibrous connective tissue containing islands of odontogenic epithelium (Figure 2D). The patient is in followup for about 28 months with no signs of recurrence and according to his attending pediatric dentist, both deciduous and permanent dentitions are normal in number and morphology.

- Case 2: A 5-month-old boy was referred for examination of a swelling on the palate. Clinical examination showed a nodule placed lateral and posterior to the incisive papilla, firm on palpation and measuring about 1.2 $\mathrm{x} 1.0 \mathrm{~cm}$ (Figure 3A). His mother reported that the lesion was present since birth and was asymptomatic. Clinical impression was of congenital epulis of the newborn and the baby was periodically followed for five months, until the parents decided to accept an excisional biopsy that was performed under general endotracheal anesthesia. During the surgery it was observed that the nodule was attached to a hard tissue with a dental crown-like morphology. No signs of bone involvement were noted since the nodule and the hard tissue were restricted to soft tissue. The patient's recovery was uneventful and histopathological analysis of the tissue displayed surface

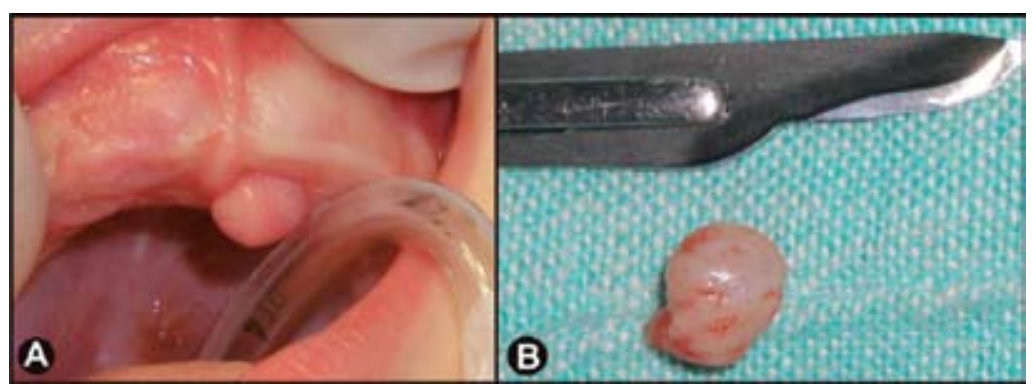

Fig. 1. A. Clinical presentation of the case 1. B. Surgical specimen exhibiting a soft tissue lesion.

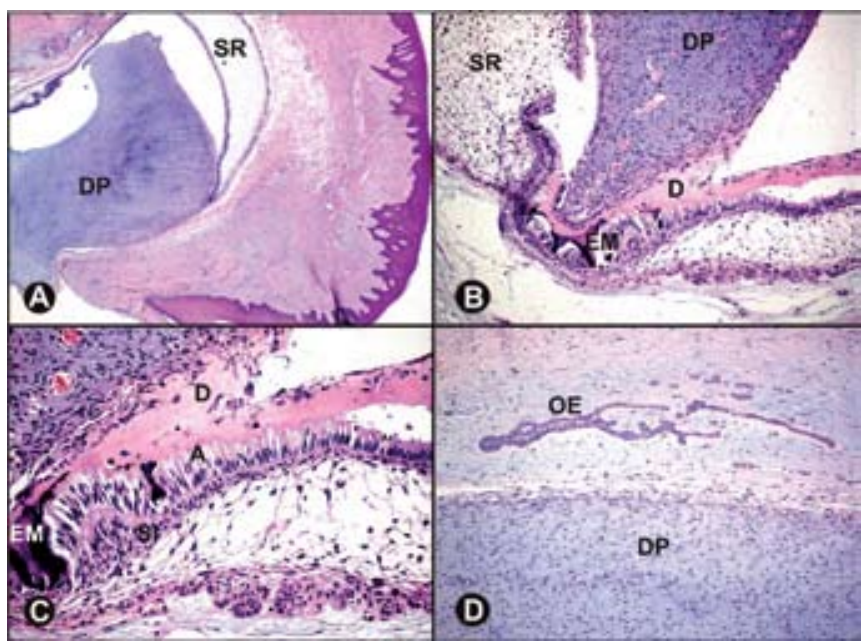

e613
Fig. 2. A. Low power view displayed surface epithelium covering a developing tooth germ composed of normal dental papilla (DP), stellate reticulum (SR) and a surrounding fibrous connective tissue $(H \& E, x 25)$. B. Medium power view revealed enamel matrix $(E M)$ and dentin (D) (H\&E, x100). C. Higher power view showed ameloblasts (A), stratum intermedium (SI) and normal dentin and enamel (H\&E, x200). D. Fibrous connective tissue rich in odontogenic epithelia (OE) (H\&E, x100). 


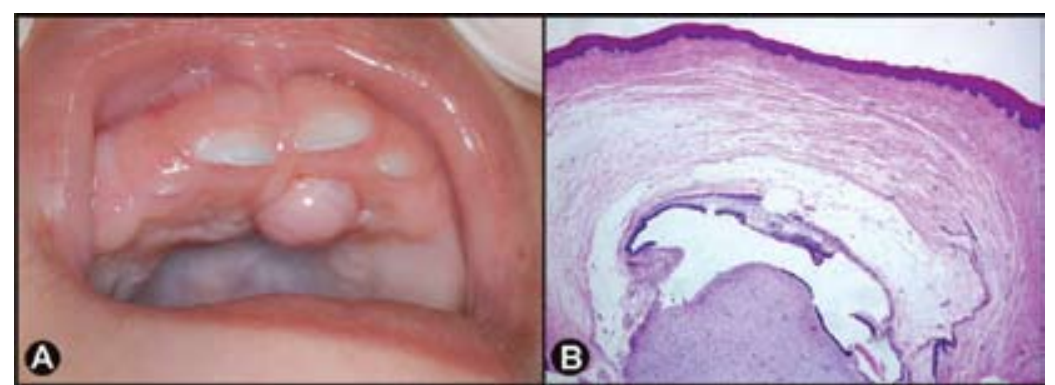

Fig. 3. A. Clinical presentation of the case 2. B. Low power view of the case 2 displayed a developing tooth germ covered by normal surface epithelium and surrounded by palatal soft tissue $(\mathrm{H} \& \mathrm{E}, \mathrm{x} 25)$

epithelium covering a developing tooth germ composed of dental papilla, stellate reticulum, mature dentin and a odontoblastic layer. The tooth germ was surrounded by a fibrous connective tissue rich in islands of odontogenic epithelium (Figure 3B). The patient is in follow-up for fifteen months without recurrence or further problems.

\section{Discussion}

Odontogenic lesions constitute a group of heterogeneous diseases that include hamartomas, cysts, benign and malignant neoplasms (1). These lesions can affect the jaws as intra-osseous (central) or extra-osseous (peripheral) entities and they are derived from epithelial and ectomesenchymal elements of the tooth-forming apparatus (8). Extra-osseous counterpart of intra-osseous odontogenic tumors are rarely observed and it is well accepted that some epithelial peripheral odontogenic tumors can arise from the soft-tissue remnants of dental lamina epithelium entrapped within the gingiva (rests of Serres) (7).

Peripheral developing odontoma is an especially rare condition with about ten cases reported on the Englishrelated literature. To the best of the authors knowledge, only four cases were described on the palate $(3,5,6,9)$ (Table 1). In all of these previously reported cases palatal nodules were present in children and after surgical exploration, tooth germs in variable stages of development were found exclusively embedded in soft tissue without bone involvement. Microscopical analysis of these cases as well as in the presented cases exhibited developing tooth germs composed of ameloblasts, enamel matrix, odontoblastic layer, dentin and dental papilla. Although varying degree of differentiation could be seem among these cases, tooth germs were invariably surrounded by dense fibrous connective tissue containing islands of odontogenic epithelium and superficially covered by normal stratified squamous epithelium.

A variety of terms such as irregular eruption, ectopic tooth, ectopic soft-tissue mesiodens, ectopic odontoma and extra-osseous tooth germ can be found in the relevant literature to describe this lesion. Conversely, recent data shows that this type of lesion forms part of the clinicopathological spectrum of peripheral odontoma and apparently this idea is shared by most oral pathologists $(9,10)$.

Different morphological features were found in the

Table 1. Previously reported cases of palatal peripheral developing odontoma.

\begin{tabular}{|l|c|c|c|c|l|}
\hline \multicolumn{1}{|c|}{ Author/year } & Age & Gender & Duration & Clinical diagnosis & \multicolumn{1}{|c|}{ Final diagnosis } \\
\hline Gans, 1962 (3) & 6 yo & M & unknown & neoplasia & Ectopic tooth \\
\hline Diekmann et al., 1982 (5) & 3 yo & M & since birth & fibroma & Ectopic soft-tissue mesiodens \\
\hline Lin et al., 1986 (6) & $17 \mathrm{mos}$ & M & since $7 \mathrm{~m}$ & fibroma & Ectopic soft-tissue mesiodens \\
\hline Kintarak et al., 2006 (9) & 13 yo & F & 5 months & fibrous hyperplasia & $\begin{array}{l}\text { Peripheral developing } \\
\text { Odontoma }\end{array}$ \\
\hline Present case 1 & $8 \mathrm{mos}$ & M & since birth & CE & $\begin{array}{l}\text { Peripheral developing } \\
\text { Odontoma }\end{array}$ \\
\hline Present case 2 & $5 \mathrm{mos}$ & M & since birth & CE & $\begin{array}{l}\text { Peripheral developing } \\
\text { Odontoma }\end{array}$ \\
\hline
\end{tabular}

Abbreviations: (yo) year old; (mos) months; (M) male; (MR) molar region; (PM) premaxila; (CE) congenital epulis of the newborn. 
previously reported cases of peripheral odontoma, including mixed odontogenic lesions without dental hard tissue (11), developing odontomas (similar to the cases presented in this paper), denticles and hard tissue masses without enamel organ structure (12). These morphological findings seem to depend on the developmental stage of each tooth germ at discovery.

Teeth completely located in soft-tissue were also found in other sites, including the upper lip, eyelid and cheek (4). In these situations we believe that the term ectopic tooth was adequately used. The presence of dental tissue outside of the alveolar process may be related to ectopic neural crest cells that would still able to differentiate into tooth germ $(3,5,6)$.

Remarkably, studies with human fetuses demonstrated with serial sections, fragmentation of the dental lamina that connected the tooth germ to the surface epithelium after morpho-differentiation and many odontogenic rests marked the former position of the dental lamina, from the gingiva to the tooth bud in its bone crypt. Some of these were located in the alveolar bone and others seen in extra-osseous locations (13). These extra-osseous rests of odontogenic epithelium could be considered a possible source that when inducted, would be able to differentiate into dental germ.

Palatal peripheral developing odontoma is uncommon and has been recognized under different names and has been found exclusively in children. Most significantly, it is important to keep in mind its clinical and histological characteristics in order to establish the proper diagnosis avoiding confusion particularly with odontogenic tumors and consequently to avoid overtreatment.

\section{References}

1. Junquera L, De Vicente JC, Roig P, Olay S, Rodríguez-Recio O. Intraosseous odontoma erupted into the oral cavity: an unusual pathology. Med Oral Patol Oral Cir Bucal. 2005;10:248-51.

2. Jones AV, Franklin CD. An analysis of oral and maxillofacial pathology found in children over a 30-year period. Int J Paediatr Dent. 2006;16:19-30.

3. Gans BJ. Ectopic tooth: report of a case. J Oral Surg Anesth Hosp Dent Serv. 1962;20:435-7.

4. El sedfy Bakry N. An ectopic odontome in the cheek. Oral Surg Oral Med Oral Pathol. 1977;43:583-4.

5. Diekmann SL, Cohen DM, Gutz DP. Ectopic soft-tissue mesiodens. Oral Surg Oral Med Oral Pathol. 1982;53:391-4.

6. Lin CC, Chen RJ, Lai S. Ectopic soft-tissue mesiodens. Report of a case. J Oral Med. 1986;41:124-5.

7. Ide F, Obara K, Mishima K, Saito I, Horie N, Shimoyama T, et al. Peripheral odontogenic tumor: a clinicopathologic study of 30 cases. General features and hamartomatous lesions. J Oral Pathol Med. 2005;34:552-7.

8. Ide F, Obara K, Yamada H, Mishima K, Saito I, Horie N, et al. Hamartomatous proliferations of odontogenic epithelium within the jaws: a potential histogenetic source of intraosseous epithelial odontogenic tumors. J Oral Pathol Med. 2007;36:229-35.

9. Kintarak S, Kumplanont P, Kietthubthew S, Chungpanich S. A nodular mass of the anterior palatal gingiva. Oral Surg Oral Med Oral Pathol Oral Radiol Endod. 2006;102:3-6.

10. Curran AE. Peripheral odontogenic tumors. Oral Maxillofac Surg Clin North Am. 2004;16:399-408.

11. Vuletin JC, Solomon MP, Pertschuk LP. Peripheral odontogenic tumor with ghost-cell keratinization. A histologic, fluorescent microscopic, and ultrastructural study. Oral Surg Oral Med Oral Pathol. 1978;45:406-15.

12. Ilief-Ala MA, Eisenberg E, Mathieu G. Peripheral complex odontoma in a pediatric dental patient: a case report. J Mass Dent Soc. 2008;56:24-6.

13. Baden E, Moskow BS, Moskow R. Odontogenic gingival epithelial hamartoma. J Oral Surg. 1968;26:702-14. 